\title{
KINERJA METODE CNN UNTUK KLASIFIKASI PNEUMONIA DENGAN VARIASI UKURAN CITRA INPUT
}

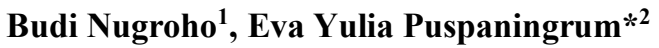 \\ ${ }^{1,2}$ Universitas Pembangunan Nasional "Veteran" Jawa Timur \\ Email: ${ }^{1}$ budinugroho.if@upnjatim.ac.id, ${ }^{2}$ evapuspaningrum.if@upnjatim.ac.id \\ *Penulis Korespondensi
}

(Naskah masuk: 17 Desember 2020, diterima untuk diterbitkan: 09 Juni 2021)

\begin{abstract}
Abstrak
Saat ini banyak dikembangkan proses pendeteksian pneumonia berdasarkan citra paru-paru dari hasil foto rontgen (x-ray), sebagaimana juga dilakukan pada penelitian ini. Metode yang digunakan adalah Convolutional Neural Network (CNN) dengan arsitektur yang berbeda dengan sejumlah penelitian sebelumnya. Selain itu, penelitian ini juga memodifikasi model CNN dimana metode Extreme Learning Machine (ELM) digunakan pada bagian klasifikasi, yang kemudian disebut CNN-ELM. Dataset untuk uji coba menggunakan kumpulan citra paru-paru hasil foto rontgen pada Kaggle yang terdiri atas 1.583 citra normal dan 4.237 citra pneumonia. Citra asal pada dataset kaggle ini bervariasi, tetapi hampir semua diatas ukuran 1000x1000 piksel. Ukuran citra yang besar ini dapat membuat pemrosesan klasifikasi kurang efektif, sehingga mesin CNN biasanya memodifikasi ukuran citra menjadi lebih kecil. Pada penelitian ini, pengujian dilakukan dengan variasi ukuran citra input, untuk mengetahui pengaruhnya terhadap kinerja mesin pengklasifikasi. Hasil uji coba menunjukkan bahwa ukuran citra input berpengaruh besar terhadap kinerja klasifikasi pneumonia, baik klasifikasi yang menggunakan metode CNN maupun CNN-ELM. Pada ukuran citra input 200x200, metode CNN dan CNN-ELM menunjukkan kinerja paling tinggi. Jika kinerja kedua metode itu dibandingkan, maka Metode CNN-ELM menunjukkan kinerja yang lebih baik daripada CNN pada semua skenario uji coba. Pada kondisi kinerja paling tinggi, selisih akurasi antara metode CNN-ELM dan CNN mencapai 8,81\% dan selisih F1 Score mencapai 0,0729. Hasil penelitian ini memberikan informasi penting bahwa ukuran citra input memiliki pengaruh besar terhadap kinerja klasifikasi pneumonia, baik klasifikasi menggunakan metode CNN maupun CNN-ELM. Selain itu, pada semua ukuran citra input yang digunakan untuk proses klasifikasi, metode CNN-ELM menunjukkan kinerja yang lebih baik daripada metode $\mathrm{CNN}$.
\end{abstract}

Kata kunci: Pendeteksian Pneumonia, Citra Paru-paru, Convolutional Neural Network, Extreme Learning Machine, dan Kinerja Klasifikasi.

\section{PERFORMANCE OF CNN METHOD FOR PNEUMONIA CLASSIFICATION WITH INPUT IMAGE SIZE VARIATIONS}

\begin{abstract}
This research developed a pneumonia detection machine based on the lungs' images from X-rays (x-rays). The method used is the Convolutional Neural Network (CNN) with a different architecture from some previous research. Also, the CNN model is modified, where the classification process uses the Extreme Learning Machine (ELM), which is then called the CNN-ELM method. The empirical experiments dataset used a collection of lung $x$-ray images on Kaggle consisting of 1,583 normal images and 4,237 pneumonia images. The original image's size on the Kaggle dataset varies, but almost all of the images are more than 1000x1000 pixels. For classification processing to be more effective, CNN machines usually use reduced-size images. In this research, experiments were carried out with various input image sizes to determine the effect on the classifier's performance. The experimental results show that the input images' size has a significant effect on the classification performance of pneumonia, both the CNN and CNN-ELM classification methods. At the 200x200 input image size, the CNN and CNN-ELM methods showed the highest performance. If the two methods' performance is compared, then the CNN-ELM Method shows better performance than CNN in all test scenarios. The difference in accuracy between the CNN-ELM and CNN methods reaches $8.81 \%$ at the highest performance conditions, and the difference in F1-Score reaches 0.0729 . This research provides important information that the size of the input image has a major influence on the classification performance of pneumonia, both classification
\end{abstract}


using the CNN and CNN-ELM methods. Also, on all input image sizes used for the classification process, the CNN-ELM method shows better performance than the CNN method.

Keywords: Pneumonia Detection, Lungs's Images, Convolutional Neural Network, Extreme Learning Machine, and Classification Performance.

\section{PENDAHULUAN}

Penyakit paru-paru banyak terjadi di seluruh dunia, diantaranya berkaitan dengan penyakit paru obstruktif kronis, asma, tuberkulosis, fibrosis, dan pneumonia (Bharati dkk, 2020). Pneumonia atau dikenal juga dengan istilah paru-paru basah adalah infeksi yang mengakibatkan peradangan pada kantong-kantong udara di salah satu atau kedua paru-paru. Biasanya penumonia ini berupa area paru yang mengalami peningkatan opasitas (Franquet, 2018). Pada penderita pneumonia, sekumpulan kantong-kantong udara kecil di ujung saluran pernapasan dalam paru-paru (alveoli) akan meradang dan dipenuhi cairan atau nanah. Akibatnya, penderita mengalami batuk berdahak, demam, menggigil, nyeri dada, dan kesulitan bernapas. Bakteri, virus, dan jamur merupakan organisme yang dapat menyebabkan pneumonia atau paru-paru basah. Namun pada penderita dewasa, kondisi ini paling sering disebabkan oleh infeksi bakteri. Gambar 1 merupakan salah satu citra digital hasil foto rontgen atau x-ray yang menunjukkan pneumonia pada salah satu bagian paru-paru seorang pasien.

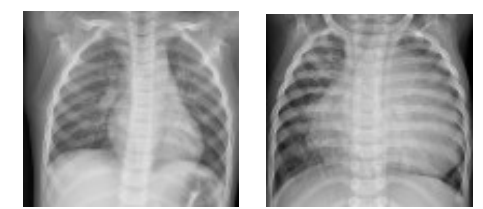

Gambar 1. Foto Rontgen / X-ray yang menunjukkan Pneumonia (gambar kanan) dan Normal (gambar kiri) [Mooney, 2019]

Pneumonia merupakan salah satu penyebab kematian pada anak tertinggi di dunia. Badan Kesehatan Dunia memperkirakan bahwa penyakit ini menjadi pemicu $15 \%$ kematian anak-anak berusia di bawah 5 tahun (WHO, 2020). Setiap tahunnya, pneumonia menjangkiti sekitar 450 juta orang, tujuh persen dari total populasi dunia, dan menyebabkan sekitar 4 juta kematian. Penemuan terapi antibiotik dan vaksin pada abad ke-20 telah meningkatkan daya tahan hidup. Meskipun demikian, di negara berkembang, dan di antara orang-orang berusia sangat lanjut, sangat muda, dan penderita sakit kronis, pneumonia tetap menjadi penyebab kematian yang utama.

Di Indonesia sendiri, berdasarkan data hasil Riset Kesehatan Dasar (Riskesdas) Kementerian Kesehatan RI, jumlah orang yang mengalami ganggunan kesehatan akibat pneumonia ini sebesar $2 \%$, mengalami peningkatan dibandingkan tahun 2013 yang sebesar 1,8\% (Kemenkes, 2018). Padahal pneumonia ini merupakan penyakit yang memiliki dampak serius yang dapat menyebabkan kematian.

Salah satu yang menyebabkan radang paruparu atau pneumonia yang saat ini sedang mewabah, bahkan menjadi pandemi global, adalah virus corona yang bernama SARS-CoV-2 yang belum pernah ditemukan sebelumnya. Pneumonia yang disebabkan oleh virus inilah yang kemudian dinamakan dengan pneumonia Covid-19. Mereka yang terinfeksi dilaporkan menderita batuk, demam, dan kesulitan bernafas. Pada kasus serius bahkan bisa terjadi kegagalan organ. Banyak di antara pasien Covid-19 yang meninggal karena sudah memiliki kondisi kesehatan yang buruk. Proses pemulihan Covid-19 tergantung pada kekuatan sistem kekebalan tubuh masing-masing individu. Pandemi Covid-19 ini tentunya semakin menempatkan pneumonia sebagai penyakit serius yang perlu penanganan secara tepat (Heidari dkk, 2020).

Banyak penelitian yang telah dilakukan berkaitan dengan masalah pneumonia. Pada tahap awal, proses pendeteksian dini sangat penting dilakukan. Salah satu teknik pendeteksian pneumonia yang saat ini banyak dikembangkan adalah klasifikasi citra paru-paru hasil foto rontgen / $\mathrm{x}$-ray. Salah satu cara mendeteksi dini pneumonia adalah dengan mengambil gambar rontgen dari bagian dada (area dimana organ paru-paru berada), kemudian mengidentifikasi apakah paru-paru mengalami peradangan (pneumonia) ataukah tidak. Banyak penelitian dilakukan yang memanfaatkan skema pembelajaran mesin untuk memprediksi informasi diagnostik dari gambar x-ray (Song dkk, 2017).

Salah satu penelitian terbaru dilakukan oleh Jain dkk yang menguji beberapa model Convolutional Neural Network (CNN), antara lain VGG16, VGG19, ResNet50, dan Inception-v3, untuk mendeteksi pneumonia (Jain dkk, 2020). Metode CNN yang digunakan tersebut memiliki efektivitas dalam pengenalan, dapat mengekstrak fitur dan klasifikasi secara otomatis. Pengujian dilakukan menggunakan basisdata citra paru-paru hasil x-ray dari Kaggle (Kaggle, 2020). Penelitian lain yang juga menggunakan metode CNN dilakukan oleh Stephen dkk, dimana arsitekturnya menggunakan 4 layer Konvolusional, 4 layer Maxpooling, 1 Flatten, 7 layer Dense, dan ditambahkan variasi skala ulang, rotasi, pergeseran lebar, pergeseran tinggi, rentang geser, rentang zoom, dan balik horizontal (Stephen dkk, 2019). Polsinelli dan tim penelitiannya menggunakan Light Convolutional Neural Network (CNN) yang didasarkan pada model 
SqueezeNet (Polsinelli dll, 2020). Xiang Xu menggunakan metode Graph-Knowledge Embbeded $\mathrm{CNN}$ untuk proses pelatihan mesin $\mathrm{CNN}$ untuk mendapatkan Ekstraktor Fitur sehingga menghasilkan kinerja klasifikasi yang tinggi ( $\mathrm{Yu}$ dkk, 2020). Sirazitdinov dkk mengkombinasikan 2 arsitektur CNN, yaitu RetinaNet dan Mask R-CNN, untuk mendapatkan kemampuan yang lebih baik dalam mendeteksi pneumonia (Sirazitdinov dkk, 2019).

Berdasarkan tinjauan berbagai penelitian sebelumnya, ukuran citra input yang digunakan untuk proses klasifikasi CNN diperkecil dari ukuran asalnya. Ukuran citra yang digunakan berbeda-beda antar peneliti. Tetapi belum ada uraian yang menjelaskan mengenai seberapa jauh pengaruh ukuran citra yang diperkecil tersebut terhadap kinerja klasifikasi. Pada penelitian ini, pengujian dilakukan terhadap beberapa ukuran cira input untuk menjawab pertanyaan tersebut. Model CNN menggunakan arsitektur dengan 23 layer keseluruhan dimana terdapat 5 layer konvolusi untuk mengklasifikasikan kondisi citra pneumonia dan non-pneumonia (normal). Selain itu juga memodifikasi arsitektur CNN tersebut pada bagian klasifikasi dengan menggunakan metode Extreme Learning Machine / ELM (Ghoneim dkk, 2019), yang selanjutnya disebut metode CNN-ELM. Proses pengujian dilakukan dengan variasi ukuran citra input untuk mengetahui pengaruhnya terhadap kinerja metode CNN dan CNN-ELM dalam mendeteksi pneumonia. Sehingga hasil penelitian ini nantinya memberikan informasi tentang pengaruh ukuran citra input terhadap kinerja klasifikasi pneumonia yang menggunakan metode CNN maupun CNN-ELM. Hal ini cukup penting mengingat kinerja klasifikasi tidak hanya bergantung pada arsitektur mesin pengklasifikasi yang digunakan, tetapi juga pada spesifikasi citra inputnya.

\section{METODE PENELITIAN}

Pendekatan klasifikasi pneumonia yang digunakan dalam penelitian ini adalah metode Convolutional Neural Network (CNN) dan Convolutional Neural Network - Extreme Learning Machine (CNN-ELM) dengan modifikasi layer yang berbeda dengan penelitian-penelitian sebelumnya. Metode CNN menggunakan 5 layer konvolusi dengan nilai filter 16, 32, 64, 128, dan 256. Proses klasifikasi menggunakan fungsi flattening, fully connected layer, dan fungsi dense. Metode CNNELM memodifikasi arsitektur CNN pada bagian klasifikasi menggunakan ELM.

Proses uji coba dilakukan dengan menggunakan dataset citra paru-paru hasil x-ray pada Kaggle yang juga digunakan oleh banyak peneliti di bidang ini. Skenario pengujian dilakukan dengan beberapa ukuran citra input untuk mengetahui pengaruhnya terhadap kinerja metode
CNN dan CNN-ELM. Sehingga, hasil uji coba akan memberikan informasi penting mengenai pendekatan CNN atau CNN-ELM yang lebih baik kinerjanya serta berapa ukuran citra yang paling tepat untuk digunakan agar kinerja klasifikasi pneumonia dapat optimal.

\subsection{Metode Klasifikasi}

Dalam implementasinya, metode

Convolutional Neural Network (CNN) dikembangkan melalui beberapa tahapan, yaitu Model Building, Model Training, Model Evaluation, dan Final Model Prediction. Struktur CNN terdiri dari dua proses yaitu ekstraksi fitur dan klasifikasi. Proses ekstraksi fitur dalam CNN terdiri dari beberapa hidden layer, yaitu lapisan konvolusi, fungsi aktifasi, dan pooling layer. $\mathrm{CNN}$ bekerja secara hierarki, sehingga output pada lapisan konvolusi pertama digunakan sebagai input pada lapisan konvolusi selanjutnya. Pada proses klasifikasi menggunakan fully-connected layer. Kedua komponen layer tersebut dapat dilengkapi dengan fungsi aktivasi (softmax) untuk optimasi pada proses CNN.

Data input memiliki sebuah ukuran piksel citra dan dilakukan proses ekstrasi pada convolution layer sehingga ukurannya akan diperkecil. Convolutional layer membentuk sebuah filter dengan panjang dan tinggi yang disebut kernel. kernel ini akan digeser keseluruh bagian dari citra input untuk mendapatkan informasi penting dari suatu obyek. Jika citra masih terlalu besar, maka untuk mengecilkan ukuran array nya akan dilakukan downsampling yang dinamakan max pooling atau mengambil nilai piksel terbesar dari setiap kernel. Pada proses pooling ukuran citra input akan dikurangi secara drastis. Meskipun begitu sekalipun mengurangi jumlah parameter, informasi penting dari citra tersebut tetap dapat terambil. Proses tersebut berlanjut hingga pooling layer terakhir yang menghasilkan ukuran citra yang sesuai. Pada bagian klasifikasi, terdapat beberapa fully connected layer. Salah satunya adalah flaten yang digunakan untuk flattening data berbentuk multidimensional array menjadi satu dimensi. Layer yang lain adalah hidden layer dan yang terakhir adalah output layer yang terdiri dari beberapa kelas yang merepresentasikan output klasifikasinya.

Data yang digunakan dibagi menjadi data training, validasi dan data uji. Kemudian merancang jaringan dengan metode CNN untuk melakukan klasifikasi. Data training digunakan untuk melakukan proses pembelajaran jaringan, kemudian dievaluasi. Apabila akurasi pada proses training model jaringan belum baik maka perlu dilakukan modifikasi pada arsitektur CNN atau pada parameter jaringan atau bisa juga pada sampel datanya. Apabila hasil akurasi sudah baik maka dilakukan proses selanjutnya yaitu pengujian dengan data validasi. Data validasi adalah data yang tidak digunakan pada proses training. Apabila akurasi dari 
data validasi ini kurang baik, mungkin terjadi overfitting, maka jaringan tersebut perlu dimodifikasi lagi. Apabila hasilnya sudah baik maka dapat digunakan untuk memproses data uji.

Adapun Arsitektur CNN yang digunakan untuk mendeteksi pneumonia pada penelitian ini ditunjukkan melalui gambar 2. Arsitektur Convolutional Neural Network yang digunakan memiliki 5 layer konvolusi, dengan nilai dimensi 16, 32, 64, 128, 256. Layer konvolusi digunakan untuk operasi konvolusi pada output dari layer sebelumnya. Layer ini merupakan aktivitas utama dalam pendekatan Convolutional Neural Network. Proses konvolusi pada data citra ini dilakukan untuk mengekstraksi fitur dari citra input. Proses ini menghasilkan transformasi linear dari data input sesuai dengan informasi spasial pada data.

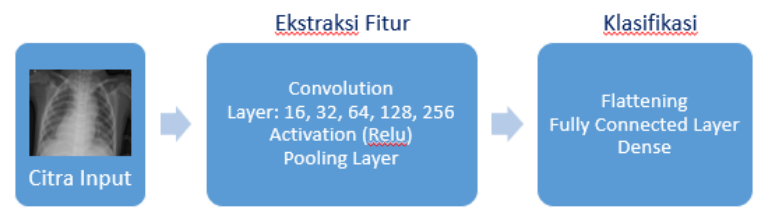

Gambar 2. Arsitektur CNN pada penelitian ini

Metode CNN pada penelitian ini juga dimodifikasi dengan menggunakan ELM pada proses klasifikasinya, sebagaimana ditunjukkan pada gambar 3. CNN digunakan pada proses ekstraksi fitur, kemudian fitur-fitur tersebut dimasukkan ke dalam mesin pengklasifikasi ELM (Kannojia, 2018). Secara teoritis, ELM memiliki kecepatan pelatihan yang cepat serta presisi pelatihan yang tinggi (Yoo, 2016). Selain itu, penggunaan ELM dapat menghasilkan kinerja CNN yang lebih baik (Kolsch, 2017).

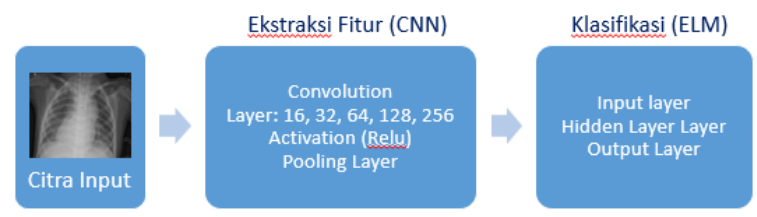

Gambar 3. Arsitektur CNN-ELM pada penelitian ini

\subsection{Dataset}

Dataset untuk proses uji coba pada penelitian ini menggunakan kumpulan citra paru-paru hasil foto rontgen (x-ray) yang tersedia pada Kaggle (Mooney, 2019), dimana data ini juga digunakan oleh para peneliti lain pada bidang ini untuk berbagi pengalaman sehingga saling mendukung untuk menghasilkan output penelitian yang lebih baik. Spesifikasi jumlah dataset tersebut, yang digunakan pada penelitian ini, ditunjukkan melalui tabel 1 . Penentuan jumlah dan spesifikasi data ini mengacu pada Kaggle yang juga digunakan oleh para peneliti lain.
Tabel 1. Spesifikasi Dataset Citra X-ray Kaggle

\begin{tabular}{ccc}
\hline Proses & Citra Normal & Citra Pneumonia \\
\hline Pelatihan & 1341 & 3875 \\
Validasi & 8 & 8 \\
Pengujian & 234 & 390 \\
\hline Jumlah & 1583 & 4273 \\
\hline
\end{tabular}

Dataset citra X-ray Kaggle tersebut memiliki 5856 citra, terdiri atas 1.583 citra normal dan 4.237 citra pneumonia, yang dikelompokkan menjadi 3 bagian, yaitu pelatihan, validasi, dan pengujian.

\subsection{Skenario Pengujian}

Proses uji coba pada penelitian ini menggunakan dataset citra pada Kaggle yang hasilnya diperoleh kinerja klasifikasi pneumonia pada proses pelatihan, validasi, dan pengujian. Kinerja klasifikasi berupa akurasi pengenalan dalam satuan persen.

Citra asal pada dataset Kaggle ini bervariasi, tetapi hampir semua di atas ukuran 1000x1000 piksel. Ukuran yang besar ini tentunya memerlukan waktu pemrosesan yang lama dan tidak efektif dilakukan. Proses klasifikasi pada CNN biasanya memodifikasi ukuran citra menjadi lebih kecil.

Pada penelitian ini, pengujian dilakukan dengan menggunakan beberapa skenario ukuran citra. Sebagaimana ditunjukkan pada tabel 2, uji coba dilakukan dengan menggunakan beberapa ukuran citra, antara lain 100x100, 200x200, 300x300, 400x400, dan 500x500 piksel. Proses pengujian dilakukan pada setiap skenario untuk menghasilkan kinerja model klasifikasi, antara lain Akurasi, Presisi, Recall, dan F1 Score. Akurasi dihitung berdasarkan rasio dari data yang diprediksi sesuai kelasnya dari keseluruhan data. Presisi dihitung berdasarkan rasio dari data yang sesuai kelasnya dibandingkan dengan data yang diprediksi positif. Recall dihitung berdasarkan rasio dari data yang diprediksi sesuai kelasnya dibandingkan dengan data yang memang sesuai kelasnya.

\begin{tabular}{ccc}
\multicolumn{3}{c}{ Tabel 2. Skenario Uji Coba } \\
\hline $\begin{array}{c}\text { Uji } \\
\text { Coba }\end{array}$ & $\begin{array}{c}\text { Ukuran Citra } \\
\text { (Piksel) }\end{array}$ & Kinerja CNN \& CNN-ELM \\
\hline 1 & $100 \times 100$ & Akurasi, Presisi, Recall, F1 Score \\
2 & $200 \times 200$ & Akurasi, Presisi, Recall, F1 Score \\
3 & $300 \times 300$ & Akurasi, Presisi, Recall, F1 Score \\
4 & $400 \times 400$ & Akurasi, Presisi, Recall, F1 Score \\
5 & $500 \times 500$ & Akurasi, Presisi, Recall, F1 Score \\
\hline
\end{tabular}

Nilai akurasi yang disajikan pada hasil penelitian ini diambil dari akurasi evaluasi berdasarkan data pengujian pada tabel 1 (234 citra normal dan 390 citra pneumonia). Demikian juga nilai presisi dan recall didasarkan pada hasil uji coba menggunakan data pengujian ini. Sedangkan F1 score dihitung berdasarkan rasio perbandingan ratarata presisi dan recall. 


\section{HASIL DAN PEMBAHASAN}

Proses uji coba yang telah dilakukan menghasilkan kinerja klasifikasi pneumonia yang ditunjukkan pada tabel 3 dan 4. Tabel 3 menunjukkan kinerja metode $\mathrm{CNN}$ pada setiap skenario uji coba yang ditentukan berdasarkan ukuran citra input yang dimodifikasi ukurannya dari citra asalnya. Sedangkan tabel 4 menunjukkan kinerja metode CNN-ELM pada setiap skenario uji coba yang ditentukan berdasarkan ukuran citra input yang digunakan.

Tabel 3. Hasil Uji Coba untuk Metode CNN

\begin{tabular}{ccccc}
\hline Citra & Akurasi & Presisi & Recall & F1 Score \\
\hline $100 \times 100$ & $82,85 \%$ & 0,8753 & 0,8462 & 0,8605 \\
$200 \times 200$ & $84,78 \%$ & 0,9019 & 0,8487 & 0,8745 \\
$300 \times 300$ & $81,57 \%$ & 0,8571 & 0,8462 & 0,8516 \\
$400 \times 400$ & $78,85 \%$ & 0,8644 & 0,7846 & 0,8226 \\
$500 \times 500$ & $77,24 \%$ & 0,8444 & 0,7795 & 0,8107 \\
\hline
\end{tabular}

Tabel 4. Hasil Uji Coba untuk Metode CNN-ELM

\begin{tabular}{ccccc}
\hline Citra & Akurasi & Presisi & Recall & F1 Score \\
\hline $100 \times 100$ & $84,78 \%$ & 0,8811 & 0,8744 & 0,8777 \\
$200 \times 200$ & $93,59 \%$ & 0,9730 & 0,9231 & 0,9474 \\
$300 \times 300$ & $88,14 \%$ & 0,9093 & 0,9000 & 0,9046 \\
$400 \times 400$ & $83,33 \%$ & 0,8803 & 0,8487 & 0,8642 \\
$500 \times 500$ & $80,77 \%$ & 0,8750 & 0,8077 & 0,8400 \\
\hline
\end{tabular}

Pada skenario 1, dimana ukuran citra inputnya 100x100 piksel, proses klasifikasi CNN menghasilkan akurasi sebesar 82,85\% dan F1 Score sebesar 0,8605 . Sedangkan proses klasifikasi CNNELM menghasilkan akurasi sebesar 84,78\% dan F1 Score sebesar 0,8777. Kinerja CNN-ELM pada skenario ini lebih baik daripada $\mathrm{CNN}$, baik akurasi maupun F1 Score-nya.

Pada skenario 2, dimana ukuran citra inputnya 200x200 piksel, proses klasifikasi CNN menghasilkan akurasi sebesar 84,78\% dan F1 Score sebesar 0,8745. Sedangkan proses klasifikasi CNNELM menghasilkan akurasi sebesar 93,59\% dan F1 Score sebesar 0,9474. Kinerja CNN-ELM pada skenario ini lebih baik daripada $\mathrm{CNN}$, baik akurasi maupun F1 Score-nya.

Pada skenario 3, dimana ukuran citra inputnya 300x300 piksel, proses klasifikasi CNN menghasilkan akurasi sebesar 81,57\% dan F1 Score sebesar 0,8516. Sedangkan proses klasifikasi CNNELM menghasilkan akurasi sebesar 88,14\% dan F1 Score sebesar 0,9046. Kinerja CNN-ELM pada skenario ini lebih baik daripada $\mathrm{CNN}$, baik akurasi maupun F1 Score-nya.

Pada skenario 4, dimana ukuran citra inputnya 400x400 piksel, proses klasifikasi CNN menghasilkan akurasi sebesar 78,85\% dan F1 Score sebesar 0,8226. Sedangkan proses klasifikasi CNNELM menghasilkan akurasi sebesar 83,33\% dan F1 Score sebesar 0,8642. Kinerja CNN-ELM pada skenario ini lebih baik daripada $\mathrm{CNN}$, baik akurasi maupun F1 Score-nya.

Pada skenario 5, dimana ukuran citra inputnya 500x500 piksel, proses klasifikasi CNN menghasilkan akurasi sebesar 77,24\% dan F1 Score sebesar 0,8107. Sedangkan proses klasifikasi CNNELM menghasilkan akurasi sebesar $80,77 \%$ dan F1 Score sebesar 0,8400. Kinerja CNN-ELM pada skenario ini lebih baik daripada $\mathrm{CNN}$, baik akurasi maupun F1 Score-nya.

Metode CNN pada hasil uji coba ini menunjukkan kinerja paling tinggi pada skenario 2 (citra input 200x200) dan kinerja paling rendah pada skenario 5 (citra input 500x500). Perbedaan kinerjanya cukup signifikan, dimana selisih akurasinya mencapai $7,54 \%$ dan selisih F1 Scorenya mencapai 0,0638 . Sedangkan Metode CNNELM menunjukkan kinerja paling tinggi ternyata juga pada skenario 2 (citra input 200x200) dan kinerja paling rendah juga pada skenario 5 (citra input 500x500). Perbedaan kinerjanya cukup signifikan, dimana selisih akurasinya mencapai 12,82\% dan selisih F1 Score-nya mencapai 0,1074.

Jika kinerja kedua metode itu dibandingkan, maka Metode CNN-ELM menunjukkan kinerja yang lebih baik daripada CNN pada semua skenario uji coba. Pada kondisi kinerja paling tinggi, selisih akurasi antara metode CNN-ELM dan CNN mencapai $8,81 \%$ dan selisih F1 Score mencapai 0,0729

\section{KESIMPULAN DAN SARAN}

Hasil penelitian ini memberikan informasi penting bahwa ukuran citra input memiliki pengaruh besar terhadap kinerja klasifikasi pneumonia, baik klasifikasi menggunakan metode $\mathrm{CNN}$ maupun CNN-ELM, dimana kinerja klasifikasi yang paling tinggi pada kondisi ukuran citra input 200x200 piksel. Pada ukuran citra input ini, akurasi metode CNN mencapai $84,78 \%$ dan F1 Score mencapai 0,8745. Pada metode CNN-ELM, akurasinya mencapai 93,59\% dan F1 Score mencapai 0,9474. Sedangkan kinerja klasifikasi yang paling rendah pada kondisi ukuran citra input 500x500 piksel. Pada ukuran citra input ini, akurasi metode CNN hanya mencapai $77,24 \%$ dan F1 Score mencapai 0,8107. Pada metode CNN-ELM, akurasinya mencapai 80,77\% dan F1 Score mencapai 0,8400.

Pada penelitian ini juga diperoleh kesimpulan bahwa metode CNN-ELM menunjukkan kinerja yang lebih baik daripada metode CNN pada semua ukuran citra input yang digunakan untuk proses klasifikasi.

Untuk pengembangan lebih lanjut, penelitian perlu dilakukan dengan menggunakan arsitektur CNN yang berbeda, untuk mengetahui apakah ukuran citra input memiliki pengaruh yang sama sebagaimana pada penelitian ini. Sehingga penelitian selanjutnya dapat menghasilkan kesimpulan mengenai ukuran citra input yang ideal untuk semua model CNN atau bahkan metode lainnya. 


\section{DAFTAR PUSTAKA}

BHARATI, S., PODDER, P., \& HOSSAIN, R., 2020. Hybrid deep learning for detecting lung diseases from X-ray images. Journal of Informatics in Medicine Unlocked 20 (2020). Publisher: Elsevier. DOI: https://doi.org/10.1016/j.imu.2020.100391

FRANQUET, T., 2018. Imaging of communityacquired pneumonia. Journal of Thoracic Imaging 2018.2 DOI: 10.1097/RTI.0000000000000347

GHONEIM, A., MUHAMMAD, G., \& HOSSAIN, M.S., 2019. Cervical cancer classification using convolutional neural networks and extreme learning machines. Journal of Future Generation Computer Systems, September 2019. Publisher: Elsevier. DOI: https://doi.org/10.1016/j.future.2019.09.015

HEIDARI, M., MIRNIAHARIKANDEHEIA, S., KHUZANIB, A.Z., DANALAA, G., QIU, Y., \& ZHENG, B., 2020. Improving the performance of $\mathrm{CNN}$ to predict the likelihood of COVID-19 using chest X-ray images with preprocessing algorithms. International Journal of Medical Informatics, Volume 144, December 2020, 104284. Publisher: Elsevier. DOI: https://doi.org/10.1016/j.ijmedinf.2020.104 284.

JAIN, R., NAGRATH, P., KATARIA, G., KAUSHIK, V.S., \& HEMANTH, D.J., 2020. Pneumonia Detection in chest X-ray images using Convolutional Neural Networks and Transfer Learning. Journal of Measurement, Volume 165, 1 December 2020, Elsevier Ltd. DOI: https://doi.org/10.1016/j.measurement.2020 .108046

KAGGLE, 2020. Chest X-Ray Images (Pneumonia). Tersedia melalui: Kaggle Chest X-Ray Images (Pneumonia) $<$ https:/www.kaggle.com/paultimothymoo ney/chest-xray-pneumonia> [Diakses 4 Agustus 2020]

KEMENKES (KEMENTERIAN KESEHATAN), 2018. Hasil Riset Kesehatan Dasar (RISKESDAS) Tahun 2018.

KANNOJIA, S.P., \& JAISWAL, G., 2018. Ensemble of Hybrid CNN-ELM Model for Image Classification. $5^{\text {th }}$ International Conference on Signal Processing and Integrated Networks (SPIN). Publisher: IEEE. DOI: https://doi.org/ 10.1109/SPIN.2018.8474196

KOLSCH, A., AFZAL, M.Z., EBBECKE, M., LIWICKI, M., 2017. Real-Time Document Image Classification using Deep CNN and Extreme Learning Machines. $14^{\text {th }}$ IAPR
International Conference on Document Analysis and Recognition (ICDAR). Publisher: IEEE. DOI: 10.1109/ICDAR.2017.217

MOONEY, P., 2019. Data of Chest X-Ray kaggle. Tersedia melalui: Kaggle $<$ https://www.kaggle.com/paultimothymoo ney/chest-xray-pneumonia $>$ [Diakses 3 Agustus 2020]

POLSINELLI, M., CINQUE, L., \& PLACIDI, G., 2020. A light CNN for detecting COVID19 from CT scans of the chest. Journal of Pattern Recognition Letters, Volume 140, December 2020, Pages 95-100. Publisher: Elsevier.

DOI: https://doi.org/10.1016/j.patrec.2020.10.00 1

SIRAZITDINOV, I., KHOLIAVCHENKO, M., MUSTAFAEV, T., YIXUAN, Y., KULEEV, R., \& IBRAGIMOV, B, 2019. Deep neural network ensemble for pneumonia localization from a large-scale chest x-ray database. Journal of Computers and Electrical Engineering 78 (2019): 388399. Publisher: Elsevier Ltd. DOI: https://doi.org/10.1016/j.compeleceng.2019 .08 .004

SONG, Q., ZHAO, L., LUO, X., DOU, X., 2017. Using deep learning for classification of lung nodules on computed tomography images. Journal of healthcare engineering 2017: $\quad 8314740 . \quad$ DOI: https://doi.org/10.1155/2017/8314740.

STEPHEN, O., SAIN, M., MADUH, U. J., \& JEONG, D., 2019. An Efficient Deep Learning Approach to Pneumonia Classification in Healthcare. Journal of Healthcare Engineering 2019 (107). DOI: $10.1155 / 2019 / 4180949$

WORLD HEALTH ORGANIZATION (WHO), 2019. Pneumonia. Tersedia melalui: World Health Organization $<$ https://www.who.int/news-room/factsheets/detail/pneumonia.html $>$ [Diakses 20 November 2020]

YOO, Y., \& SE-YOUNG, O., 2016. Fast training of convolutional neural network classifiers through extreme learning machines. 2016 International Joint Conference on Neural Networks (IJCNN). Publisher: IEEE. DOI: 10.1109/IJCNN.2016.7727403

YU, X., WANG, S., ZHANG, Y., 2021. CGNet: A graph-knowledge embedded convolutional neural network for detection of pneumonia. Information Processing \& Management, Volume 58, Issue 1, January 2021, 102411. Publisher: Elsevier. DOI: https://doi.org/10.1016/j.ipm.2020.102411 